\title{
Could the Mexica toztli have been a sun parakeet? Connecting Mexica featherwork to South America
}

Vers une nouvelle identification du toztli : connexions entre la plumasserie aztèque et l'Amérique du Sud

Hacia una nueva identificación del toztli: vínculos entre el arte plumerío Mexicay America del Sur

Louise Deglin

\section{(2) OpenEdition}

Journals

Electronic version

URL: https://journals.openedition.org/jsa/17282

DOI: 10.4000/jsa. 17282

ISSN: $1957-7842$

\section{Publisher}

Société des américanistes

Printed version

Date of publication: 20 December 2019

Number of pages: 93-105

ISSN: 0037-9174

\section{Electronic reference}

Louise Deglin, "Could the Mexica toztli have been a sun parakeet? Connecting Mexica featherwork to South America", Journal de la Société des américanistes [Online], 105-2 | 2019, Online since 20

December 2019, connection on 04 September 2022. URL: http://journals.openedition.org/jsa/17282 ; DOI: https://doi.org/10.4000/jsa. 17282 


\title{
Could the Mexica toztli have been a sun parakeet? Connecting Mexica featherwork to South America
}

\author{
Louise DegLIN *
}

Colorful feathers were an important part of the regalia and martial attributes of the Mexicas, who used them on headdresses, shields, capes, but also on the images of their gods. Despite the early interest of Europeans in the American featherwork, some bird species used by the amanteca remain undetermined to this day. The thorough study of two manuscripts written under the direction of Fray Bernardino de Sahagún, the Primeros Memoriales and the Florentine Codex, has revealed an inconsistency between the way the toztli, or "yellow parrot," has been described and depicted in the colonial sources, and its current identification as the Amazona oratrix. This bird is more likely to have been a rarer specimen, native to lands located far from the Mexica heartland. [Key words: featherwork, Mexica, Aztec, yellow parrot, Florentine Codex, Primeros Memoriales, toztli.]

Vers une nouvelle identification du toztli : connexions entre la plumasserie aztèque et l'Amérique du Sud. Les plumes bigarrées constituaient une part importante de l'apanage régalien et martial des Aztèques (couvre-chefs, rondaches, capes, etc.), qui ornaient également leurs divinités de phanères d'oiseaux tropicaux. Pour autant, en dépit de l'intérêt porté très tôt par les Européens pour la plumasserie des Amériques, certaines espèces ornithologiques utilisées par les Aztèques dans leurs œuvres de plumes demeurent à ce jour indéterminées. L'étude attentive de deux manuscrits rédigés sous la direction de Fray Bernardino de Sahagún, les Primeros Memoriales et le Codex Florentin, a ainsi révélé une incohérence entre les représentations et descriptions coloniales du toztli, ou « perroquet jaune », et son identification actuelle comme l'Amazona oratrix. Il est probable que cet oiseau soit en effet un spécimen plus rare, originaire de territoires bien éloignés du cœur de l'Empire aztèque. [Mots-clés : plumasserie, Mexica, Aztèque, perroquet jaune, Codex Florentin, Primeros Memoriales, toztli.]

Hacia una nueva identificación del toztli: vínculos entre el arte plumerío Mexica y America del Sur. Las plumas abigarradas constituían una parte importante de las prerrogativas reales y marciales de los Mexicas (sombreros, escudos, capas, etc.),

* Ph.D. student, Department of Art History, University of California, Los Angeles, USA [louisedeglin@g.ucla.edu]. 
que también adornaban sus divinidades con plumas de aves tropicales. A pesar de que los Europeos se interesaron temprano al arte plumario de las Américas, ciertas especies ornitológicas utilizadas por los Mexicas en sus obras aun son indeterminadas. El estudio atento de dos manuscritos redactados bajo la dirección de Fray Bernardino de Sahagún, los Primeros Memoriales y el Códice Florentino, reveló así una incoherencia entre las representaciones y descripciones coloniales del toztli, o "papagayo amarillo", y su identificación actual como la Amazona oratrix. Es probable que esta ave sea en efecto una especie más rara, originaria de territorios bien alejados del corazón del Imperio Mexica. [Palabras clave: plumería, Mexica, Azteca, papagayo amarillo, Códice Florentino, Primeros Memoriales, toztli.]

Shimmering Mesoamerican feathers have mesmerized Europeans from very early on: in 1556, the "Anonymous Conquistador" expressed his awe when beholding "one garment [...] covered with a layer of feathers of different colors, making a fine effect" (Filloy Nadal and Olvido Moreno Guzman 2017, p. 162). Exotica par excellence, symbol of the Americas (Mongne 2014a, p. 7), feathers were praised for their delicacy by both Indians and non-Indians at the time. The idea of New Spain could be reduced to the sole mention of feathers: on the Ricci map that was printed in 1602 in Hangzhou, China, the region is accompanied by the following comment:

The land of Mexico produces bird feathers of all colors. The people collect them and make them into paintings. The landscapes and humans figures (they do) are all marvellous [sic]. (Russo 2015, p. 60)

Many scholars and conservators are familiar with this topic, which has been investigated repeatedly since the 19th century (Denis 1875). Despite the prolific literature that has been published on the subject, however, many questions remain to be answered or reassessed, such as the identification of the bird species that the Aztec-Mexica ${ }^{1}$ featherworkers used in their productions. Indeed, if some species are amply documented by early colonial sources, and others have been determined through modern analytical techniques, several have not yet been convincingly identified. In addition, uncertainties arise as the field of ornithology keeps growing, bird species being regularly recategorized or even discovered: in 2017, scholars identified a new species of parrot in Mexico, the blue-winged Amazon (Amazona gomezgarzai; Silva et al. 2017).

It should be stressed that early texts referencing New Spain's avifauna and featherwork are very limited in number. Researchers mainly refer to the tribute section of the Codex Mendoza, and to book IX ("De los mercaderes") and book XI ("De las cosas naturales") of the Florentine Codex. Late pre- and early post-invasion indigenous documents such as the Codex Borbonicus do seem to depict very specific kinds of birds (Gilonne 1977), but they provide

1. Hereby referred to as Mexica. 
no further information. Hence, historic sources should be handled with care, for they may be plagued with incoherences or approximations, and cannot be combined with a broad corpus of artifacts surviving from before the Spanish arrival. Many incompatibilities appear when coupling volumes on New Spain's natural history with contemporary knowledge about Mexica avifauna: are some species now extinct? Are some still unknown to modern ornithologists? Or are the descriptions in the colonial written sources inaccurate? The fact is, almost five centuries after the fall of Tenochtitlan, much is still to be learned about Mexica featherwork.

It is not recent news that feathers have been, and are still today, highly valued by indigenous peoples of the Americas (Mongne 2014b, p. 53). According to the Codex Mendoza, they composed a significant part of the tribute imposed by the Mexica upon their provinces, and according to the Florentine Codex, some amanteca (featherwork specialist) were entirely dedicated to the creation of courtly paraphernalia (Filloy Nadal and Olvido Moreno Guzman 2017, p. 169). Feathers covered the images of the Mexica sacred forces, the heads of their rulers, and the bodies of their warriors. To that end, long-distance trade routes were implemented throughout the empire and beyond (Mongne 2014a, p. 15), providing the Mexica elite with precious and colorful appendages of tropical birds. From the present-day Southeastern United States to the southern coast of Peru, parrots have especially been sought after by indigenous groups of the Americas for their vibrant feathers, imported from the jungle of Central America and Amazonia. Today, numerous species of parrots are listed as endangered, including all the subspecies of the well-known scarlet macaw (Ara macao) since February $2019,{ }^{2}$ reflecting the high demand for those colorful birds. Indeed, the disappearance of those parrots is mainly related to human actions such as the destruction of the natural habitat of the birds, and their capture for pet trade. ${ }^{3}$

Considering the upsetting consequences of the European invasion and the political, social, and economic reorganization that ensued in the Americas, exchange networks that provided feathers to non-tropical regions must have been interrupted in the second half of the 16th century. Therefore, the species used to produce feather artifacts in colonial times may have differed from the ones used before the contact with Europeans, and the absence of a type of bird on colonial feather mosaics should not negate the possibility of it having been used earlier in time.

2. See the list of endangered parrot species on the U.S. Fish \& Wildlife Service website: https://www.fws.gov/endangered/what-we-do/parrots.html (consulted 21/11/19).

3. See "Scarlet Macaw Receives Endangered Species Act Protections," News Release, February 25, 2019, U.S. Fish \& Wildlife Service, Office of Public Affairs. 


\section{Feathers in the Primeros Memoriales}

For this study, I will of course refer to the Florentine Codex as a primary source of information, but I will also make use of a considerably less studied document: the Primeros Memoriales. Compiled between 1558 and 1561 in the city of Tepepolco by Fray Bernadino de Sahagún and four indigenous artists, this ensemble of 645 folios documents the religious, political, and military life and accoutrement of the Mexica. Sometimes considered a mere draft of the Florentine Codex, the Primeros Memoriales was actually thoroughly elaborated (Quiñones Keber 1997, p. 16), illustrating local knowledge in an encyclopedic manner. The main interest of this volume lies in its association of Nahuatl texts and lexicon with colored illustrations, hence enabling non-Mexica readers to envision events, concepts, and artifacts that are alien to them. In the Primeros Memoriales, many bird species are indicated in Nahuatl when detailing costumes and insignia, providing us with precious information on their use. How are these feathers depicted in the corresponding illustrations?

Throughout the many folios that compose the Primeros Memoriales, nine bird species are named when referring to feathers: the cotinga (Cotinga amabilis), the heron (Ardeidae), the quetzal (Pharomacrus mocinno), the yellow parrot, the turkey hen (Meleagris gallopavo), the hummingbird (Selasphorus), the scarlet macaw (Ara macao), the eagle (Aquila chrysaetos), and the roseate spoonbill (Ajaia ajaja) (Davis 1972). Most of these species such as the quetzal or the cotinga, are well known to Mesoamerican specialists and their use is attested on feather mosaics, shields, and headdresses housed in museums worldwide (Riedler 2015). When detailing the depiction of such feathers in the Primeros Memoriales, and especially in its section dedicated to Mexica deities (f. 261 to 267), one is struck by the coherence of the colors used. Indeed, quetzal feathers are consistently painted in green, heron and eagle in white, red macaw in orange, cotinga in blue, and roseate spoonbill in pink, which corresponds to the hues of their respective plumage. The use of pink especially, such a rare color in indigenous and early colonial documents, does imply that the painter in charge of this section sought to replicate nature with his palette. Why, then, did he depict the yellow parrot feathers in blue?

\section{Current identification of the yellow parrot}

A mistake on the part of the tlacuilo (painter) seems quite unlikely. Indeed, the two deities with which this bird is associated appear in first place in the listing of the gods: Huitzilopochtli, the patron of the Mexicas, and his delegate Paynal. Both were therefore highly regarded by the Mexica population, and the traces of sketches on the two figures ${ }^{4}$ reveal that they were meticulously

4. For example, on Paynal's shield. 
elaborated by the artist. In both cases, the headdresses are designated in Nahuatl as "ytozpulol," where "toz" refers to the color yellow. What could have possibly justified the use of blue on the two divine adornments? This incongruity was already noted by Eduard Seler (Seler 1908, p. 168), who could not come to any conclusive explanation.

The feathers of the yellow parrot are further mentioned in the Primeros Memoriales: on the yellow parrot tunic, ${ }^{5}$ the yellow parrot xolotl headdress, ${ }^{6}$ on the quetzal-bestrewn headdress with the face covered in yellow parrot feathers, ${ }^{7}$ and on the yellow parrot serpentine insignia. ${ }^{8}$ On these, the yellow parrot feathers are, as expected, painted yellow. But strikingly, the icuçuyavalol, a "circular fan of yellow parrot feathers" (Sullivan and Nicholson 1997) worn by rulers as a regalia in their hair, ${ }^{9}$ is painted half-yellow and half-blue on several occurrences, with sections in red and green. Was this, again, an initiative of the tlacuilo's imagination, or did this coloration correspond to a reality?

In early colonial literature, the yellow parrot is designated in Nahuatl as both "toznene" and "toztli." According to book XI of the Florentine Codex, the toznene (Figure 1) can be defined as follows:

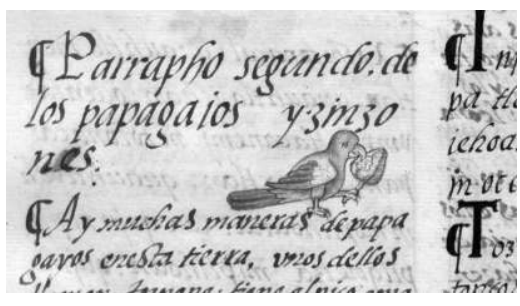

Fig. 1 - Toznene. Historia general de las cosas de nueva Espana (1577), vol. 3, book XI, f. 23r, Biblioteca Medicea Laurenziana, Florence, Ms. Med. Palat. 220, http://teca.bmlonline.it.

It has a yellow, curved bill, like that of the white-fronted parrot; the head is crested. Its breeding place is especially [the province of] Cuextlan. These are its chicks feathers - herb green, dark, dark green on its back, and about its neck, and its tails, and its wings. And those at the tip of its wing-bend are green (and) yellow; they cover its flight feathers. And on its breast, on its belly, its feathers are yellow, dark yellow. They are called xollotl. And its tail and its wings are ruddy. (Sahagún 1963, p. 22)

The toztli would actually be the adult toznene (Figure 2, next page), differing slightly:

When the young (yellow) parrot is already developed, it turns yellow, it becomes very yellow. It develops fluffy feathers. When completely feathered, then it is called toztli. (Sahagún 1963, p. 23)

5. Mentioned on f. $68 \mathrm{r}$ and $72 \mathrm{v}$, depicted on the latter folio.

6. Mentioned and depicted on f. $72 \mathrm{v}$.

7. Mentioned on f. $68 \mathrm{r}$, depicted on $73 \mathrm{v}$.

8. Mentioned on f. $68 \mathrm{v}$ and depicted on f. $77 \mathrm{v}$.

9. Mentioned and depicted on f. 51r and 52r. 


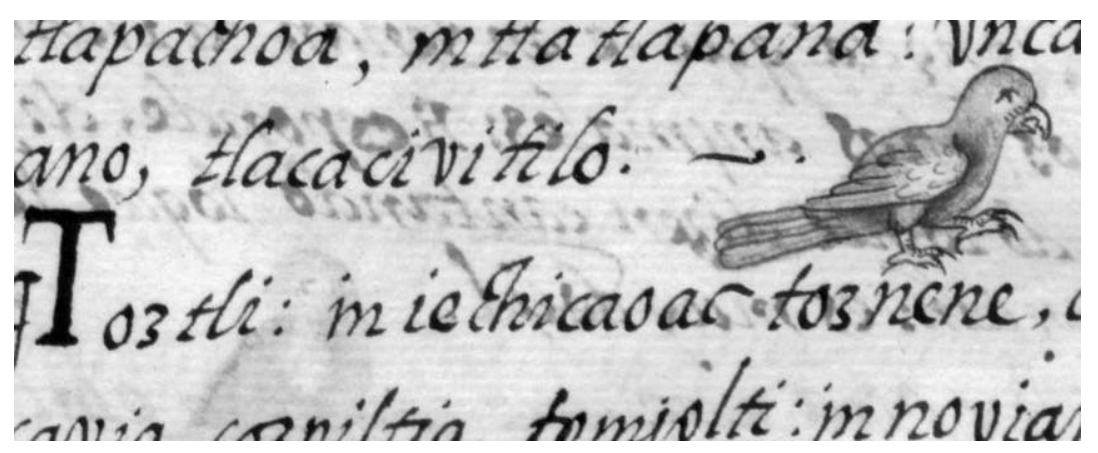

Fig. 2 - Toztli. Historia general de las cosas de Nueva Espana (1577), vol. 3, book XI, f. 22v, Biblioteca Medicea Laurenziana, Florence, Ms. Med. Palat. 220, http://teca.bmlonline.it.

As of today, the toznene and toztli (which belong to the same species according to the Florentine Codex) have not been unanimously identified. They are mainly said to be two different ages of the yellow-headed parrot (Amazona oratrix, see Figure 3; Mongne 2012, p. 9; Filloy Nadal and Olvido Moreno Guzman 2017, table 6.3; Reyes Equiguas 2011, p. 301), but they have also been identified as the green macaw (Ara militaris; Reyes Equiguas 2011, p. 301) or as the montezuma oropendola (Psarocolius montezuma; Berdan 2015, p. 327). However, these species hardly correspond to the descriptions and depictions of the toznene and the toztli in the Florentine Codex. They differ on several aspects, but overall lack one major point: their bodies are covered in green or black feathers instead of yellow, when this color gave its name to the bird. Why would the Florentine Codex insist on the species being "very yellow" (Sahagún 1577, f. 23r), and why would the tlacuilo depict it accordingly, if the parrot in question was predominantly green? Unconvinced by the suggestion that the Amazona oratrix is the indigenous yellow parrot, Michel Gilonne has dismissed the issue by positing that the toztli may have become extinct since the 16th century, as it has not been recorded by ornithologists (Gilonne 1977, p. 40).

\section{A yellow parrot from South America}

Since the Florentine Codex's account of the yellow parrot mentions that it was bred on the Gulf Coast (the Cuextlan province roughly corresponds to present-day Veracruz), scholars have limited their propositions to the Mexican avifauna. Nevertheless, I suggest that the toztli being raised on Mexica soil does not necessarily imply that it originated from there. Indeed, the Mexica practice of breeding birds in captivity, particularly to provide material for featherworkers, is well documented in the literature: for example, "[ $\mathrm{t}]$ he amantecas who 


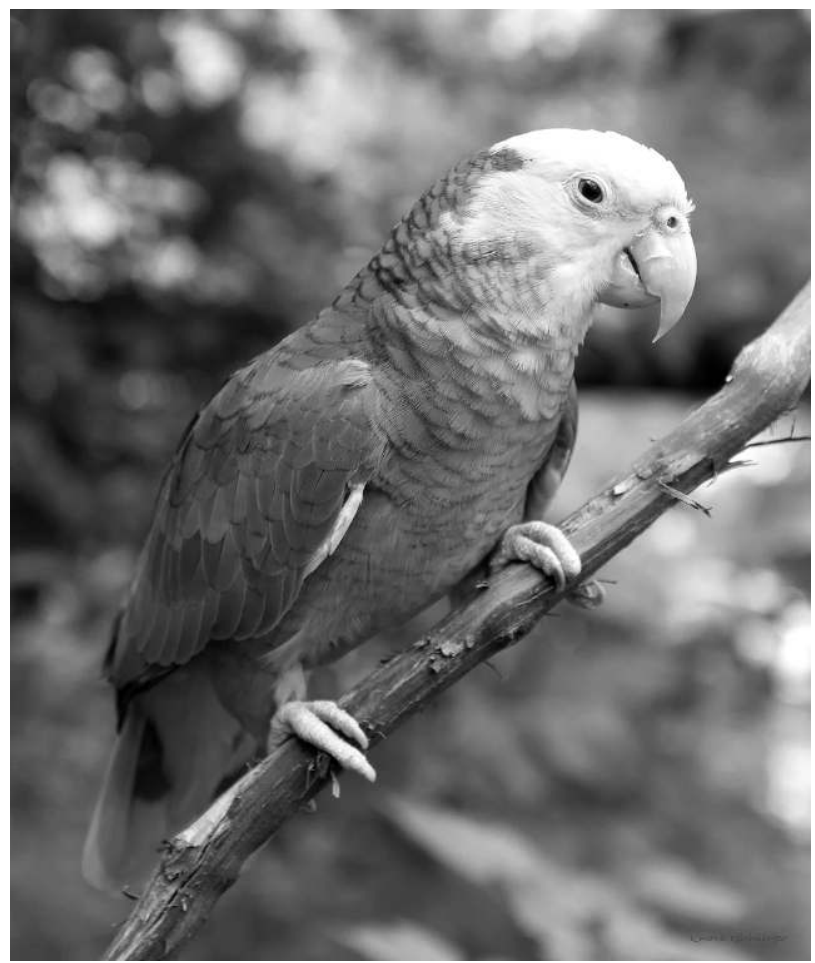

Fig. 3 - Yellow Headed Amazon (E_monk, Tuxedo, 2019) (C) e monk (CC BY-NC-SA 2.0).

worked in the palace [of Tenochtitlan] could also obtain feathers from the royal zoo" (Filloy Nadal and Olvido Moreno Guzman 2017, p. 183). According to Pascal Mongne, in the art of featherwork, "the collection of living birds must have been the norm"10 (Mongne 2014a, p. 12). Thus, could the toztli have been brought from southern lands?

In effect, one species of bird, not endemic to Mexico, almost perfectly fits the description made of the toznene and toztli in the Florentine Codex. The sun parakeet, or sun conure (Aratinga solsticialis), strikingly resembles both the written and the pictorial accounts of the yellow parrot: the young sun parakeet displays vivid green feathers on its back (Figure 4, next page), while its head and belly are covered in yellow with touches of red. When maturing, the bird becomes predominantly yellow (Figure 5, next page), still highlighted with patches of red and green. In addition, the blue feathers that decorate the adult sun conure's tail could also account for the blue headdresses of Huitzilopochtli and Paynal in the

10. Translation by the author. 


\section{Louise DegLIN}

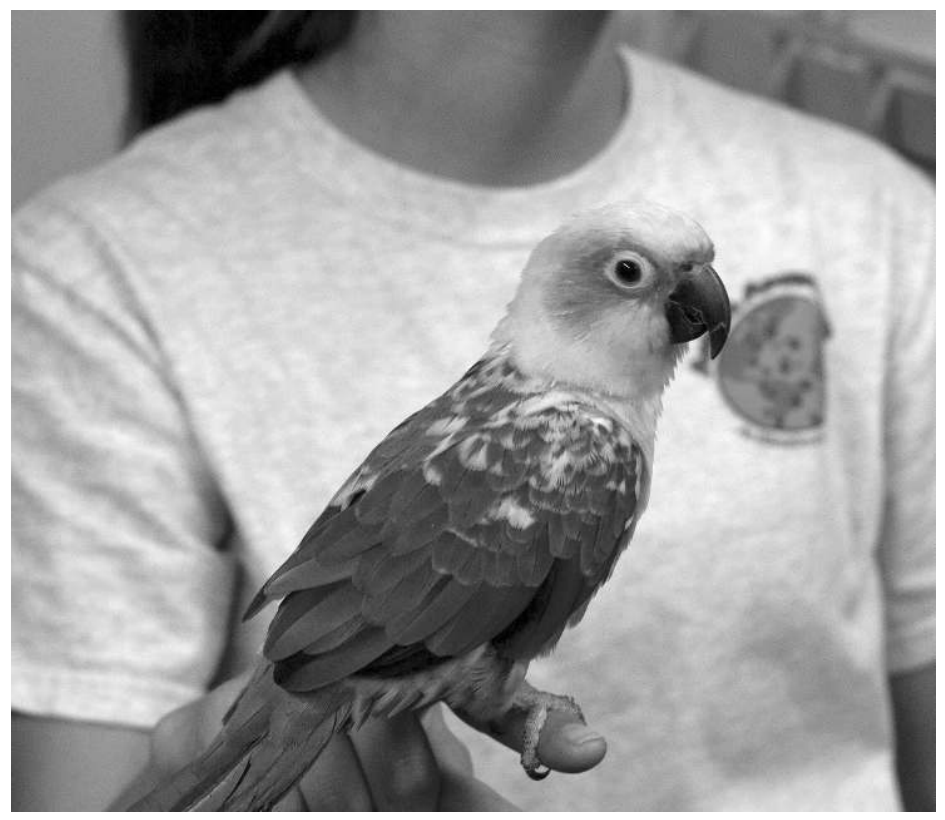

Fig. 4 - Young Sun Conure (Savage, 2012)

(C) Eric Savage (CC BY-SA 2.0).

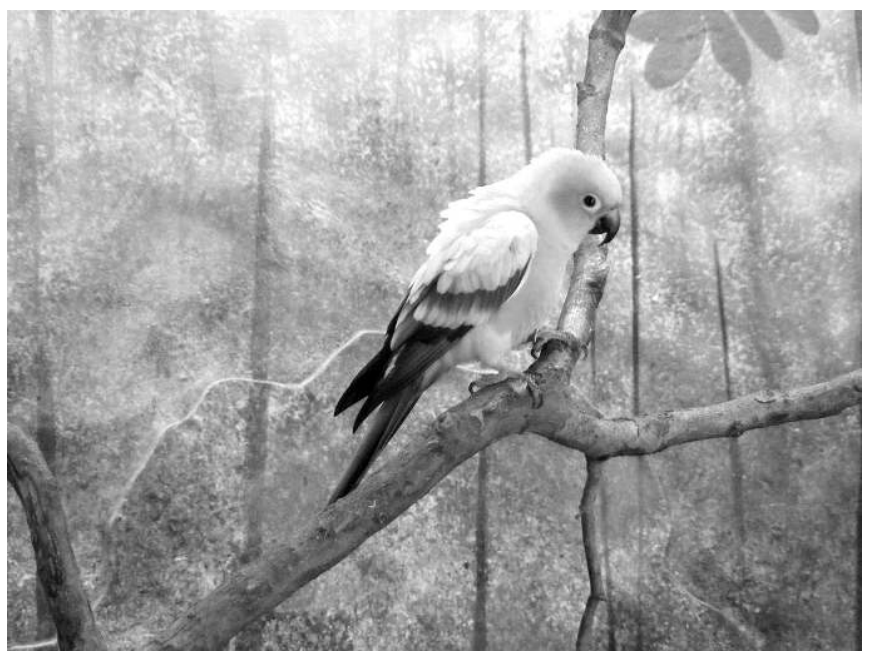

Fig. 5 - Sun Conure (Roche, Brookfield Zoo, 2007) (C) Richard Roche (CC BY-NC 2.0). 
Primeros Memoriales. It should be noted that the Aratinga solsticialis, with its flamboyant plumage, does coincide very well with the solar imagery associated with the Mexica patron Huitzilopochtli. Overall, the only detail in which the sun conure (Aratinga solsticialis) differs from the toznene description in the Florentine Codex concerns its beak, which is actually dark and not yellow.

In book XI of the Florentine Codex, the yellow parrot is also mentioned as a comparison to the cocho; the latter is said to resemble the young yellow-headed parrot (Sahagún 1577, f. 23v), the toznene, with dark green feathers and touches of red and yellow. It seems that the cocho has been unanimously identified as the white-fronted parrot (Amazona albifrons; Mongne 2014b; Filloy Nadal and Olvido Moreno Guzman 2017), even if this species does not display any yellow apart from its beak. The white-fronted parrot and the young sun parakeet (Aratinga solsticialis) do not look markedly alike, but they do share a similar silhouette and a dense green hue. This argument thus neither disproves nor confirms the sun parakeet's case.

Regarding the sun parakeet's origin, its natural habitat is located in the coastal region of the Guyanas and the northeastern border of the Brazilian forest. Albeit situated thousands of miles from the Mexican Gulf coast, the two regions do share a similar tropical climate on their littoral zone. It has been shown that the Mexica provinces that provided tribute in feathers to the central power were not always the regions producing these feathers (Mongne 2014a, p. 18). Therefore, one could go as far as imagining that the four mysterious handles of green and yellow feathers depicted on f. 46r of the Codex Mendoza could belong to the toztli, as Pascal Mongne has already suggested (ibid., p. 18). In that case, the surprisingly low number of feathers of this type would be explained by the fact that they come from the precious sun parakeet (Aratinga solsticialis), and not simply from a yellow-headed amazon (Amazona oratrix).

The golden parakeet (Guaruba guarouba), also from the Psittacidae family and native to the northern Amazon, could also be a likely candidate. With its clear beak and uniformly yellow

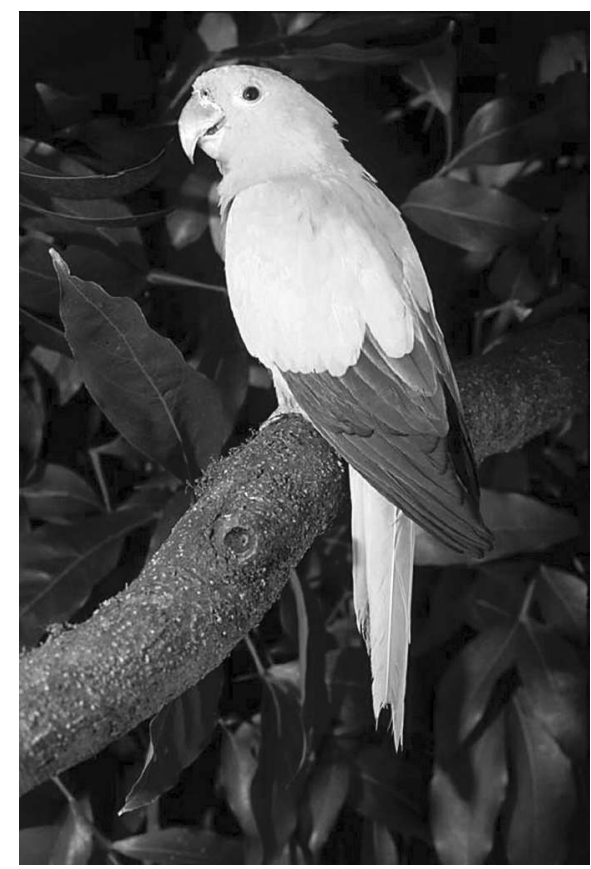

Fig. 6 - Golden parakeet

(Galaviz, Brazil, 2008) (C) Rogelio A. Galaviz C. (CC BY-NC 2.0). 
plumage (Figure 6), it strikingly corresponds to the textual description of the toztli. However, it lacks the distinctive red patches mentioned in the text and depicted on the illustrations of the Florentine Codex.

\section{Aviculture or "tapirage"?}

Aviculture was a well-developed practice in North America before the 16th century. Scarlet macaws (Ara macao) were imported from Southern Mexico by the Mimbres people, established from the 11th to the 13th century in what is today the American Southwest (Creel and McKusik 1994). In order to do so, the birds would have traveled at least $1100 \mathrm{~km}$, whether carried by foot or by boat (Crown 2016). Remains of both green macaws (Ara militaris) and scarlet macaws (Ara macao) were found at the site of Paquime, in northwestern Mexico (Holeman 2014). While both were found buried alive in cages, it seems that only the scarlet macaw was bred in captivity, as remains of this bird at different ages, including eggshells, were recovered (ibid., p. 129). Hence, parrot aviculture could take many forms in the ancient Americas, including in regions with a non-tropical climate.

Ornithologist Allison Schultz considers that sun parakeets (Aratinga solsticialis) could easily survive on the Gulf coast of Mexico, especially as some are even presently thriving on the coast of Florida. ${ }^{11}$ American parakeets and parrots were commonly traded and sold in France during the late 17th and early 18th century, where they served as distinguished pets far from their natural habitat (Robbins 2002, p. 113). The Spanish invasion and the end of aviculture in the Mexica empire may even be enough to account for the disappearance of the sun parakeet in Mexico, following what Michel Gilonne had foreseen (Gilonne 1977). Indeed, Dr. Schultz posits that parrots bred in captivity may not have survived in the wilderness in the 16th century; the birds may even have been killed instead of being released after the Spanish invasion. ${ }^{12}$ Overall, if a South American parrot was raised in captivity far from its natural habitat, it would have likely been fragile and may not have survived on the Gulf Coast without specific care.

Another possibility to explain the origin of the yellow parrot would be the practice of "tapirage", or "contrafeitos" in Portuguese, as described by Alfred Métraux in 1928 (Métraux 1928; Buono 2009). This artificial modification of bird feathers' color by Tupi and Karib groups in northern Amazonia is performed directly on living birds. "Tapirage" consists of applying a tinted mixture to

11. See https://ebird.org/map/sunpar1?neg=true\&env.minX=\&env.min $Y=\&$ env.maxX $=$ \&env. $\operatorname{maxY}=\& z h=$ false $\& \mathrm{gp}=$ false $\&$ ev $=\mathrm{Z} \& \mathrm{mr}=1-12 \& \mathrm{bmo}=1 \& \mathrm{emo}=12 \& \mathrm{yr}=\mathrm{all} \& \mathrm{byr}=1900 \&$ eyr $=2019$ (consulted 21/11/19).

12. Dr. Allison Schultz, personal communication, February 28, 2019. 
plucked birds that will alter the hue of the future feathers (Métraux 1928, p. 183-184); most often, the blood of the dyeing poisonous frog (Dendrobates tinctorius) is used, mixed with other substances to give a yellow or red color to the feather that will consequently grow on the bird (Buono 2009, p. 292). However, the final effects would have been that of colored spots rather than a uniform tint (Métraux 1928, p. 185). Hence, the hypothesis of the yellow parrot feathers being the result of "tapirage" seems less likely than that of the breeding of colorful birds from remote regions, especially as this practice has not been attested outside of northern Amazonia.

\section{Conclusion}

Both the Aratinga solsticialis and the Guaruba guarouba species from South America show significant similarities with the description and depiction of the toznene and the toztli of the Florentine Codex, more than any endemic species presently known in Mexico. The outstanding distance that would have been traveled to obtain the feathers of these birds, or more probably the birds themselves, does seem questionable. However, other indigenous societies in the Americas had already established large-scale trade networks since the first millennium CE in order to obtain birds or feathers, from the Nasca in the Central Andes to the Mimbres in the American Southwest.

The remoteness of the parrots' habitat would have justified the rarity of their feathers associated with the patron deity of the Mexica, with the emperors themselves, and with highly ranked warriors. All parts of the young toznene and the adult toztli, from yellow to blue feathers, would have been used if the colored illustrations of the Primeros Memoriales are correct. The collapse of the Mexica empire could logically account for the disappearance of these birds after the Spanish invasion, especially as aviculture was put to an end. Hence, could a South American bird species have been bred in the Mexica empire? Further research might someday ascertain this hypothesis, attesting contacts between the two continents. *

* Manuscrit reçu en mars 2018, accepté pour publication en mai 2019. 


\section{References cited}

BERDAN Frances F.

2015 "Amantecayotl glyphs in the Florentine Codex", in Alessandra Russo, Gerhard Wolf, and Diana Fane (eds), Images take flight. Feather art in Mexico and Europe 1400-1700, Hirmer, Munich, p. 322-329.

Buono Amy J.

2009 "Tupi featherwork and the dynamics of intercultural exchange in Early Modern Brazil", in Jaynie Anderson (ed.), Crossing cultures. Conflict, migration and convergence, Miegunyah Press, Victoria, p. 291-295.

CreEl Darrell and Charmion McKusIK

1994 "Prehistoric macaws and parrots in the Mimbres area, New Mexico", American Antiquity, 59 (3), p. 510-524.

CRown Patricia L.

2016 "Just macaws: a review for the U.S. Southwest/Mexican Northwest", KIVA, 82 (4), p. 331-363.

DAVIS L. Irby

1972 A field guide to the birds of Mexico and Central America, University of Texas Press, Austin.

Denis Ferdinand

1875 Arte Plumaria. Les plumes, leur valeur et leur emploi dans les arts au Mexique, au Pérou, au Brésil, dans les Indes et dans l'Océanie, Ernest Leroux, Paris.

Filloy Nadal Laura and María Olvido Moreno Guzman

2017 "Precious feathers and fancy fifteenth-century feathered shields", in Deborah L. Nichols, Frances F. Berdan, and Michael E. Smith (eds), Rethinking the Aztec economy, University of Arizona Press, Tucson, p. 156-194.

GiLonne Michel

1977 “L'avifaune dans le Codex Borbonicus", Journal de la Société des américanistes, 64, p. 29-42.

Holeman Abigail

2014 "The parrots of paquime: a look at the role of aviculture in thirteenth-century Northern Mexico", in Benjamin S. Arbuckle, and Sue Ann McCarty (eds), Animals and inequality in the ancient world, University Press of Colorado, Boulder, p. 125-144.

MÉTRAuX Alfred

1928 'Une découverte biologique des Indiens de l'Amérique du Sud : la décoloration artificielle des plumes sur les oiseaux vivants", Journal de la Société des américanistes, 20, p. 181-192.

Mongne Pascal

2012 "In tototl in amanteca. Les oiseaux de la plumasserie aztèque", Les Dossiers du GEMESO [online], 2, http://www.gemeso.com/wp-content/ uploads/2010/05/11mai-2012-GEMESO-2-der.pdf, consulted 21/11/19.

2014a "La Huella de los Tlacuilos Tradición y aculturación en la Misa de san Gregorio del Museo des Jacobins de Auch (Francia)", Baessler-Archiv, 61, p. 7-27.

2014 b "Le chemin des plumes. De l'oiseau à la parure dans la plumasserie aztèque", Ethnozootechnie, 96, p. 53-68. 
QuiÑONES KeBER Eloise

1997 "An introduction to the images, artists, and physical features of the Primeros Memoriales", in Thelma D. Sullivan, and Henry B Nicholson (eds), Primeros memoriales. Paleography of Nahuatl text and English translation, University of Oklahoma Press, Norman, p. 15-37.

Reyes Equiguas Salvador

2011 "Identificación de las aves mencionadas en los Cantares", in Miguel León Portilla (ed.), Cantares Aztecnos, Universidad Nacional Autónoma de México/ Fideicomiso Teixidor, Mexico, p. 297-302.

RIEDLER Renée

2015 "Materials and technique of the feather shield preserved in Vienna", in Alessandra Russo, Gerhard Wolf, and Diana Fane (eds), Images take flight. Feather art in Mexico and Europe 1400-1700, Hirmer, Munich, p. 330-341.

RobBins Louise E.

2002 Elephant slaves and pampered parrots. Exotic animals in eighteenth-century Paris, Johns Hopkins University Press, Baltimore.

Russo Alessandra

2015 "A contemporary art from New Spain", in Alessandra Russo, Gerhard Wolf, and Diana Fane (eds), Images take flight. Feather art in Mexico and Europe 14001700, Hirmer, Munich, p. 22-63.

SAHAGún Bernardino de

1577 Florentine Codex. Historia general de las cosas de Nueva España, Biblioteca Medicea Laurenziana, Florence, Ms. Mediceo Palatino 218-220.

1963 Florentine Codex. General history of the things of New Spain, translated by Charles E. Dibble and Arthur J.O. Anderson, University of Utah Press, Salt Lake City, vol. XI.

SELER Edouard

1908 "Costumes et attributs des divinités du Mexique selon le P. Sahagún", Journal de la Société des américanistes, 5, p. 163-220.

Silva Tony, Antonio Guzmán, Adam D. Urantówka, and Pawel Mackiewicz

2017 “A new parrot taxon from the Yucatán Peninsula, Mexico: its position within genus Amazona based on morphology and molecular phylogeny", PeerJ, 5: e3475, https://peerj.com/articles/3475/, consulted 21/11/19.

Sullivan Thelma D. and Henry B. Nicholson

1997 Primeros memorials. Paleography of Nahuatl text and English translation, University of Oklahoma Press, Norman. 
